\title{
CO-ORDINATION OF PHOTOSYNTHESIS AND STOMATAL RESPONSES OF MONGOLIAN OAK (QUERCUS MONGOLICA FISCH. EX LEDEB.) TO ELEVATED O3 AND/OR CO 2 LEVELS
}

\author{
WANG, L. L. ${ }^{1 *}-$ LI, Y. Y. ${ }^{1 *}-$ LI, X. M. ${ }^{1}-$ MA, L. J. ${ }^{1}-$ HE, X. Y. ${ }^{2}$ \\ ${ }^{1}$ College of Life Science, Shenyang Normal University \\ No. 253 Huanghe North Street, Shenyang, Liaoning 110034, China \\ ${ }^{2}$ Institute of Applied Ecology, Chinese Academy of Sciences \\ No. 72 Wenhua Road, Shenyang, Liaoning 110016, China \\ *Corresponding authors \\ e-mail:wangqi5387402006@163.com,yueyinglicn@163.com
}

(Received 25 $5^{\text {th }}$ Dec 2018; accepted $26^{\text {th }}$ Feb 2019)

\begin{abstract}
Four-year-old trees grown in open-top chambers (OTCs) were exposed to elevated $\mathrm{O}_{3}$ $(80 \mathrm{nmol} / \mathrm{mol}, \mathrm{EO})$ or $/$ and elevated $\mathrm{CO}_{2}(700 \mu \mathrm{mol} / \mathrm{mol}, \mathrm{EC})$ levels. The object is to study the responses of photosynthesis and stomata in leaves of Mongolian oak (Quercus mongolica) to EO and/or EC for two successive growing seasons in an urban area. The experiment was conducted in the arboretum located at the center of Shenyang city. The results show that: (1) EO decreased $P_{n}$ (Light-saturated net photosynthesis rate), $g_{s}$ (stomatal conductance) and $T_{r}$ (transpiration rate). The stomata closure maybe associated with the direct effect of $E O$ on guard cells. The decreases of $F_{0}, F_{m}$ and $F_{v} / F_{m}$ indicated that EO limits the capability of the plant to use photon energy and thus alters photosynthesis. (2) EC increased $P_{n}$ and $\mathrm{C}_{\mathrm{i}}$ (intercellular $\mathrm{CO}_{2}$ concentration) of leaves, but decreased $\mathrm{g}_{\mathrm{s}}$ and $\mathrm{T}_{\mathrm{r}}$ slightly. Stomatal density decreased significantly at the end of the second season. Perhaps, EC was detected by mature leaves in the first season which signaled to the developing leaves in the next season, the stomatal developments of which altered accordingly. (3) Under EC+EO, EC relieved most of the $\mathrm{O}_{3}$-induced adverse effects to $\mathrm{P}_{\mathrm{n}}$. The decreases of $g_{s}$ and $T_{r}$ were mainly caused by EO. There was no significant difference of $F_{v} / F_{m}$ detected compared to the control, EC can largely relieve the adverse effects of EO on the PSII reaction center. Changes of stomatal parameters were just like the changes under EC. Perhaps the morphological changes of the stomata were mainly caused by EC.
\end{abstract}

Keywords: photosynthetic $\mathrm{CO}_{2}$ exchange, chlorophyll fluorescence, stomatal density, stomatal area

Abbreviations: $\mathrm{C}_{\mathrm{a}}$ : concentration of ambient $\mathrm{CO}_{2} ; \mathrm{C}_{\mathrm{i}}$ : concentration of intercellular $\mathrm{CO}_{2} ; \mathrm{F}_{\mathrm{m}}$ : fluorescence maximum; $F_{0}$ : fluorescence origin; $F_{v} / F_{m}:$ maximum quantum yield of PSII photochemistry; $\mathrm{g}_{\mathrm{s}}$ : stomatal conductance; $\mathrm{P}_{\mathrm{n}}$ : light-saturated net photosynthesis rate; $\mathrm{T}_{\mathrm{r}}$ : transpiration rate

\section{Introduction}

Since the industrial revolution, accumulating greenhouse gas $\left(\mathrm{O}_{3}\right.$ and $\left.\mathrm{CO}_{2}\right)$ levels have increased over two-fold (Guo et al., 2017). The atmospheric concentrations of $\mathrm{CO}_{2}$ have increased since 1750. In 2011, the concentration of $\mathrm{CO}_{2}$ was $391 \mu \mathrm{mol} / \mathrm{mol}$ and exceeded the pre-industrial levels by about $40 \%$. The rise primarily resulted from emissions of fossil fuel burning and secondarily from net land use change (IPCC, 2013). This rise has been accompanied by the increase in troposphere $\mathrm{O}_{3}$ concentrations, which is not only a significant greenhouse gas but is also recognized as a serious phytotoxic air pollutant that damages plants (Serengil et al., 2011). As concentrations of NOx and VOCs increase through industrialization and vehicle exhausts, the daily surface $\mathrm{O}_{3}$ levels in industrialized countries have increased remarkably from $10 \mathrm{nmol} / \mathrm{mol}$ prior to the industrial revolution to $60 \mathrm{nmol} / \mathrm{mol}$ in the current summer seasons, and are predicted to increase by another 
$20 \%$ by 2050 (IPCC, 2007). Ground-level $\mathrm{O}_{3}$ concentrations have significantly increased over the past decades, especially in northeast Eurasian region (Akimoto et al., 2015; Feng et al., 2015; Verstraeten et al., 2015).

These two co-occurring pollutants are quite interesting as they act in diametrically different directions. Stomatal aperture and density influence the rate of photosynthesis and transpiration of plant directly. Regulation of stomatal development and stomatal conductance is a key factor for plant in its adaptation to the environment changes and plants have evolved sophisticated mechanisms to control stomata density and behavior (Engineer et al., 2014). The stomatal control is achieved by the regulation of stomatal aperture through changes in guard cell turgor, and by alteration of stomatal density through modification of stomatal initiation and leaf expansion during leaf development (Haworth et al., 2013). Research of Frey et al. (1996) showed that stomatal density of birch could be increased under a consistently $\mathrm{O}_{3}$ exposure. A reduction in stomatal conductance is commonly observed in response to elevated $\mathrm{CO}_{2}$ (Woodward, 1987). Reported changes in stomatal density with growth at elevated $\mathrm{CO}_{2}$ include increases, decreases, and no change (Drake and Gonzàlez-Meler, 1997). Those species with little or no control of stomatal aperture were more likely to exhibit a reduction in stomatal density under elevated $\mathrm{CO}_{2}$ (Haworth et al., 2013). But how can stomatal response to both elevated $\mathrm{O}_{3}$ and elevated $\mathrm{CO}_{2}$ ? The stomatal development and stomatal conductance of leaves would how to be regulated to adapt to the combinational environments? The objective of this study was to measure photosynthetic and stomatal parameters of leaves of Q. mongolica (Quercus mongolica) trees grown in open-top chambers (OTCs) for two growing seasons to evaluate the photosynthesis and stomata responses of $Q$. mongolica to elevated concentrations of $\mathrm{O}_{3}$ and/or $\mathrm{CO}_{2}$. Cities are with concentrated industrial plants and heavy traffic. Trees grown in urban regions are more likely affected by elevated $\mathrm{O}_{3}$ and $\mathrm{CO}_{2}$, so the OTCs of this experiment were built in the center of the city to simulate the $\mathrm{O}_{3}$ and $\mathrm{CO}_{2}$ effects on leaves of $Q$. mongolica.

\section{Research design and methods}

\section{Site and OTCS}

The experiment site is located in Shenyang Arboretum of Chinese Academy of Sciences $\left(41^{\circ} 46^{\prime} \mathrm{N}, 123^{\circ} 26^{\prime} \mathrm{E}\right.$ and $41 \mathrm{~m}$ above sea level), which is located in the metropolitan area of Shenyang, Liaoning province, China). In this area, average annual precipitation is $755.4 \mathrm{~mm}$ and average annual temperature is $7.4{ }^{\circ} \mathrm{C}$. The mean daytime temperature and the mean relative humidity in the OTCs showed no significant differences among treatments (Tmean $=26{ }^{\circ} \mathrm{C}$ Hmean $=70 \%$ ). Ambient rainfall was occasionally supplemented to minimize water stress. The soil in the OTCs was loamy, supplemental fertilizer was provided and weeds were removed regularly. The factorial design of the OTCs has already been reported, they are $4 \mathrm{~m}$ in diameter and $3 \mathrm{~m}$ in height with a $45^{\circ}$ sloping frustum, and distance among them is at least $4 \mathrm{~m}$ (He et al., 2006). There are twelve OTCs provided for four treatments, each with 3 replicates (in 3 OTCs randomly). The treatments were (1) control (ambient air, CK), (2) elevated $\mathrm{O}_{3}(80$ nmol $/ \mathrm{mol} \mathrm{O}_{3}+$ ambient $\mathrm{CO}_{2}, \mathrm{EO}$ ), (3) elevated $\mathrm{CO}_{2}$ (ambient $\mathrm{O}_{3}+700 \mu \mathrm{mol} / \mathrm{mol} \mathrm{CO}_{2}$, $\mathrm{EC})$, (4) elevated $\mathrm{O}_{3}+$ elevated $\mathrm{CO}_{2}\left(80 \mathrm{nmol} / \mathrm{mol} \mathrm{O}_{3}+700 \mu \mathrm{mol} / \mathrm{mol} \mathrm{CO}_{2}, \mathrm{EO}+\mathrm{EC}\right)$.

$\mathrm{O}_{3}$ was produced from bottled pure oxygen with an ozone generator (GP-5J, China) and pure $\mathrm{CO}_{2}$ was injected into the chambers from cylinders. In order to monitor $\mathrm{O}_{3}$ and $\mathrm{CO}_{2}$ concentrations, $\mathrm{O}_{3}$ transducer (S-900, Aeroqual, New Zealand) and $\mathrm{CO}_{2}$ infrared 
transducer (SenseAir, Sweden) were used inside the chambers. Elevated $\mathrm{CO}_{2}$ was applied for $24 \mathrm{~h} /$ day. Elevated $\mathrm{O}_{3}$ was applied for $9 \mathrm{~h} /$ day (08:00-17:00).

\section{Plant material}

In April, uniform and healthy Q. mongolica trees (four-year-old) from local nursery were randomly planted in the soil of twelve OTCs (three OTCs were used as replicates for each treatment), 20 trees per chamber. These young trees were exposed to CK, EO and/or EC from 18 June to 10 October in the first season, overwintered in the OTCs and then reexposed from 18 June to 10 October in the second season.

\section{Gas exchange measurements}

One leaf per plant and three plants per OTC (three OTC $\mathrm{OT}_{\mathrm{S}}$ per treatment, $n=9$ ) were measured by a portable photosynthesis system (LI-6400, Li-Cor Inc., Lincoln NE, USA) to attain a mean value every 15 days. The same method of gas exchange measurements has been reported (Wang et al., 2009).

\section{Chlorophyll a fluorescence measurements}

Chlorophyll a fluorescence was measured once every 15 days at ambient temperature in the OTC's in the second year, using a portable fluorometer (Handy-PEA, Hansatech, England). One leaf per plant and three plants per OTC (three OTCs per treatment, $n=9$ ). The environmental conditions were similar to gas exchange measurement. The same method of Chlorophyll a fluorescence measurement has been reported (Wang et al., 2009).

\section{Stomatal parameters measurements}

Q. mongolica leaves were collected after 0,60 days (in the first season) and 210 days exposure (in the second season). Three leaf per plant, three plants per OTC and three OTC $_{\text {s per treatment }}(n=27)$. The top, middle and bottom of leaves were painted with transparent nail polish, and then the films were torn off after it dried. The temporary microscopic slides of dried nail polish were observed and photographed with picture pickup system of bright-field microscope (Olympus BX-50, 1.3 million pixels), and image processing software (Motic Images Advanced 3.0) was used to measure and calculate the stomatal parameters including stomatal density, stomatal length, stomatal width, stomatal perimeter and stomatal area.

\section{Statistical analysis}

ANOVA was carried out using SPSS 13.0 computer package to analyze all sets of data and the means were compared by the Tukey test at 5\% probability Levels. Sample variability is given as the standard deviation (S.D.) for presentation.

\section{Results}

\section{Effects of elevated $\mathrm{O}_{3}$ and/or $\mathrm{CO}_{2}$ on Pn, gs, Ci and Tr of Q. mongolica leaves}

EO suppressed $\mathrm{P}_{\mathrm{n}}$ of $Q$. mongolica leaves significantly $(\mathrm{p}<0.05)$ over two growing seasons compared to the control. The maximum difference (about $72 \%$ ) was recorded 
after 45 days exposure in the first season, while EC increased it generally. $\mathrm{P}_{\mathrm{n}}$ of leaves exposed to $\mathrm{EO}+\mathrm{EC}$ was generally significantly higher than that exposed to $\mathrm{EO}$ alone, but lower than control except the last measurement (Fig. $1 a$ and $b$ ).

In the first season, there was decrease of $C_{i}$ detected in the EO environment compared to the control. While in the second season, there was almost no significant difference between EO and control treatments. However, EC and EO+EC treatments increased $\mathrm{C}_{\mathrm{i}}$ of leaves compared to the control, and it was higher under $\mathrm{EC}$ than $\mathrm{EO}+\mathrm{EC}$ (Fig. $1 c$ and $d$ ).

EO and EO+EC generally decreased $g_{s}$ of leaves significantly $(p<0.05)$, compared to the control and EC alone. However, there was no significant difference between $\mathrm{EO}+\mathrm{EC}$ and EO treatments except after 60 days exposure in the second season. Compared to the control, EC slightly decreased $\mathrm{g}_{\mathrm{s}}$ of leaves over the two growing seasons (Fig. le and $f$ ).

Similar change was shown between $\mathrm{T}_{\mathrm{r}}$ and $\mathrm{g}_{\mathrm{s}}$ of $Q$. mongolica leaves (Fig. $1 g$ and $h$ ).

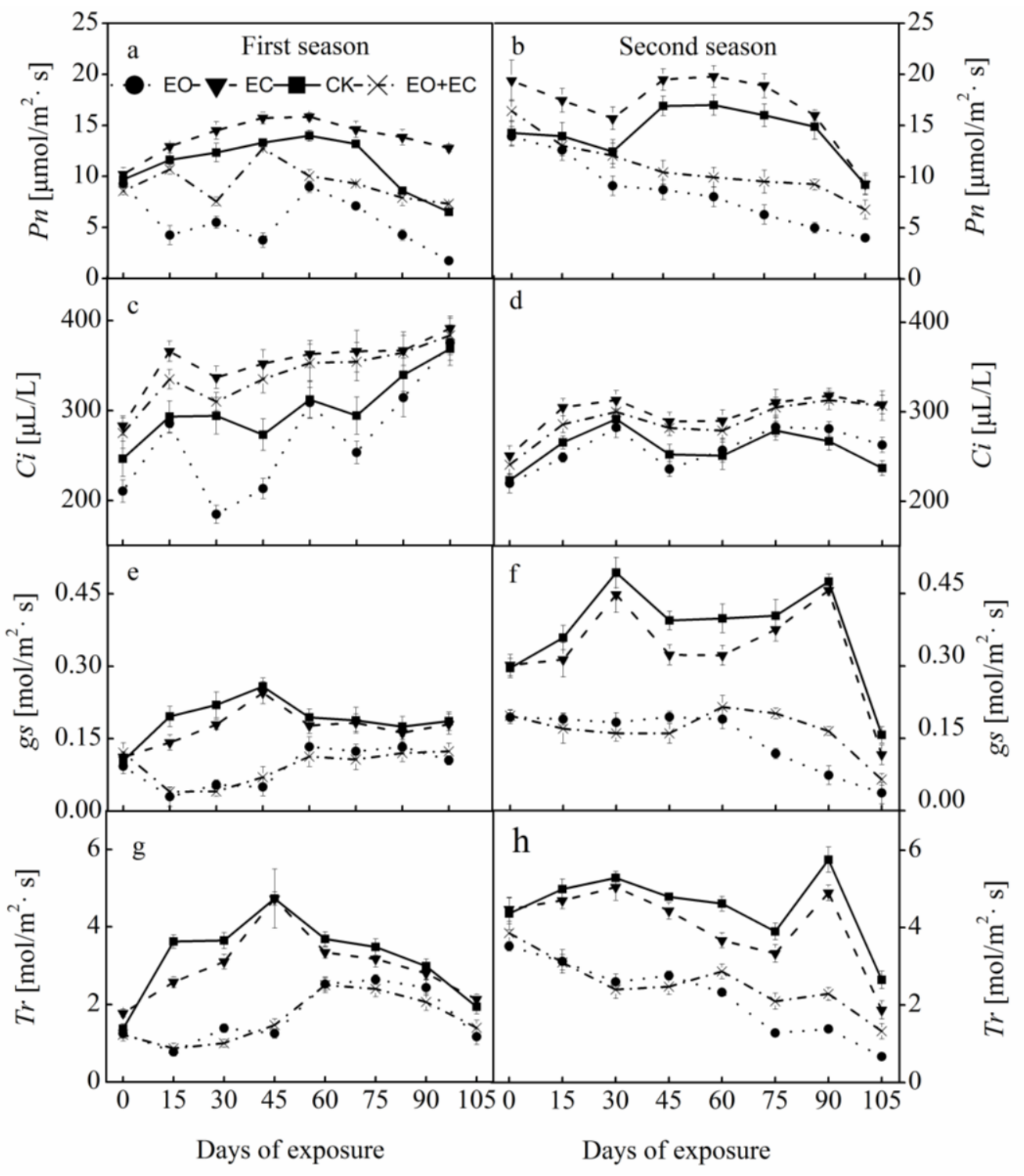

Figure 1. Effect of elevated $\mathrm{CO}_{2}$ and/or $\mathrm{O}_{3}$ on the seasonal changes of $P_{n}, g_{s}, C_{i}$ and $T_{r}$ of $Q$. mongolica leaves. Each value represents the mean $\pm S D$ 


\section{Effects of elevated $\mathrm{O}_{3}$ and/or $\mathrm{CO}_{2}$ on chlorophyll fluorescence parameters of $Q$. mongolica leaves}

EO decreased $\mathrm{F}_{0}, \mathrm{~F}_{\mathrm{m}}$ and $\mathrm{F}_{\mathrm{v}} / \mathrm{F}_{\mathrm{m}}$ of $Q$. mongolica leaves after 75 days in the second season compared to the control. The differences were significant in the later dates $(\mathrm{P}<0.05)$, but there was no significant differences detected in other treatments (Fig. 2).

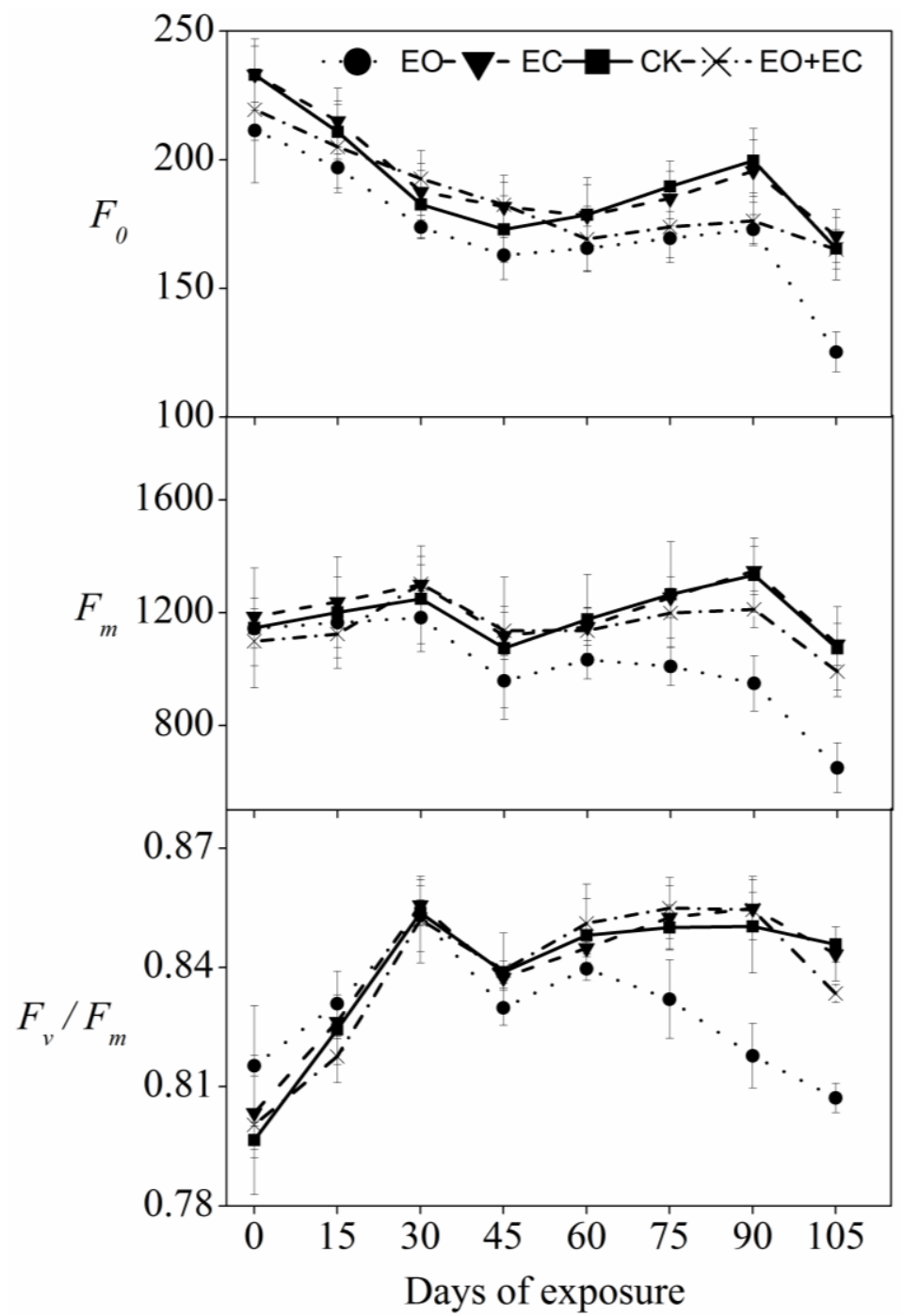

Figure 2. Effect of elevated $\mathrm{CO}_{2}$ and/or $\mathrm{O}_{3}$ on the seasonal changes of $\mathrm{F}_{0}, \mathrm{Fm}$ and $\mathrm{Fv} / \mathrm{Fm}$ (the maximum quantum yield of PSII photochemistry) of $Q$. mongolica leaves. Each value represents the mean $\pm S D$

\section{Effects of elevated $\mathrm{O}_{3}$ and/or $\mathrm{CO}_{2}$ on stomatal parameters of $Q$. mongolica leaves}

There was no difference of stomatal density of leaves detected in all the treatments in fist season (0th, 60th day in the first season), but in the end of the second season (210th day), EC and EO+EC significantly decreased it compared to the control $(\mathrm{P}<0.05)$. There was only a slight increase of stomatal width of leaves by EC compared to the control on 60th day $(\mathrm{P}<0.05)$. There were no significant differences of stomatal length, stomatal perimeter and stomatal area of leaves in the all treatments (Table 1). 
Table 1. Effect of elevated $\mathrm{CO}_{2}$ and/or $\mathrm{O}_{3}$ on stomatal density, length, width, perimeter and area of $Q$. mongolica leaves.

\begin{tabular}{|c|c|c|c|c|c|c|}
\hline $\begin{array}{c}\text { Days of } \\
\text { exposure }\end{array}$ & Treatments & $\begin{array}{c}\text { Stomatal } \\
\text { density } \\
\left(\mathrm{No} / \mathbf{m m}^{2}\right)\end{array}$ & $\begin{array}{c}\text { Stomatal } \\
\text { length } \\
(\mu \mathrm{m})\end{array}$ & $\begin{array}{c}\text { Stomatal } \\
\text { width } \\
(\mu \mathrm{m})\end{array}$ & $\begin{array}{c}\text { Stomatal } \\
\text { perimeter } \\
(\mu \mathrm{m})\end{array}$ & $\begin{array}{c}\text { Stomatal } \\
\text { area } \\
\left(\mu \mathbf{m}^{2}\right) \\
\end{array}$ \\
\hline \multirow{4}{*}{0 days } & CK & $293.00 \pm 22.03^{\mathrm{a}}$ & $72.72 \pm 5.21^{\mathrm{a}}$ & $23.20 \pm 1.42^{\mathrm{a}}$ & $204.91 \pm 18.80^{\mathrm{a}}$ & $1553.1 \pm 197.1^{\mathrm{a}}$ \\
\hline & EO & $293.05 \pm 19.01^{\mathrm{a}}$ & $73.91 \pm 4.01^{\mathrm{a}}$ & $23.51 \pm 1.73^{\mathrm{a}}$ & $205.70 \pm 16.51^{\mathrm{a}}$ & $1555.0 \pm 173.6^{\mathrm{a}}$ \\
\hline & EC & $293.01 \pm 20.16^{\mathrm{a}}$ & $74.13 \pm 5.72^{\mathrm{a}}$ & $24.05 \pm 1.91^{\mathrm{a}}$ & $206.27 \pm 11.59^{a}$ & $1548.3 \pm 178.4^{\mathrm{a}}$ \\
\hline & $\mathrm{EO}+\mathrm{EC}$ & $293.00 \pm 18.05^{\mathrm{a}}$ & $73.50 \pm 6.51^{\mathrm{a}}$ & $23.47 \pm 1.58^{\mathrm{a}}$ & $206.05 \pm 25.62^{\mathrm{a}}$ & $1545.5 \pm 113.0^{\mathrm{a}}$ \\
\hline \multirow{4}{*}{60 days } & $\mathrm{CK}$ & $293.05 \pm 25.02^{\mathrm{a}}$ & $76.06 \pm 7.22^{\mathrm{a}}$ & $21.05 \pm 1.53^{\mathrm{b}}$ & $203.04 \pm 16.72^{\mathrm{a}}$ & $1541.0 \pm 179.7^{\mathrm{a}}$ \\
\hline & EO & $293.00 \pm 19.01^{\mathrm{a}}$ & $76.11 \pm 4.03^{\mathrm{a}}$ & $22.21 \pm 1.66^{\mathrm{ab}}$ & $204.72 \pm 12.12^{\mathrm{a}}$ & $1597.3 \pm 166.2^{\mathrm{a}}$ \\
\hline & $\mathrm{EC}$ & $291.47 \pm 10.10^{\mathrm{a}}$ & $77.10 \pm 6.20^{\mathrm{a}}$ & $23.58 \pm 1.31^{\mathrm{a}}$ & $205.41 \pm 20.01^{\mathrm{a}}$ & $1646.6 \pm 105.8^{a}$ \\
\hline & $\mathrm{EO}+\mathrm{EC}$ & $284.86 \pm 24.32^{\mathrm{a}}$ & $76.04 \pm 7.14^{\mathrm{a}}$ & $22.02 \pm 2.15^{\mathrm{ab}}$ & $203.60 \pm 18.88^{\mathrm{a}}$ & $1597.0 \pm 102.7^{\mathrm{a}}$ \\
\hline \multirow{4}{*}{210 days } & $\mathrm{CK}$ & $366.00 \pm 16.90^{\mathrm{a}}$ & $65.92 \pm 6.82^{\mathrm{a}}$ & $18.09 \pm 1.11^{\mathrm{a}}$ & $174.21 \pm 19.12^{\mathrm{a}}$ & $913.8 \pm 167.5^{\mathrm{a}}$ \\
\hline & EO & $350.43 \pm 22.60^{\mathrm{a}}$ & $66.07 \pm 4.38^{\mathrm{a}}$ & $18.22 \pm 1.44^{\mathrm{a}}$ & $175.83 \pm 13.64^{\mathrm{a}}$ & $923.3 \pm 108.4^{\mathrm{a}}$ \\
\hline & $\mathrm{EC}$ & $325.67 \pm 12.00^{\mathrm{b}}$ & $67.03 \pm 4.31^{\mathrm{a}}$ & $18.53 \pm 1.62^{\mathrm{a}}$ & $181.11 \pm 16.63^{\mathrm{a}}$ & $967.2 \pm 117.2^{\mathrm{a}}$ \\
\hline & $\mathrm{EO}+\mathrm{EC}$ & $319.09 \pm 15.70^{\mathrm{b}}$ & $67.31 \pm 5.90^{\mathrm{a}}$ & $18.61 \pm 1.40^{\mathrm{a}}$ & $181.21 \pm 11.21^{\mathrm{a}}$ & $968.6 \pm 134.9^{a}$ \\
\hline
\end{tabular}

Each value represents the mean \pm SD. (Different letters indicate significant differences between treatments at the same time at $\mathrm{P}<0.05$ )

\section{Discussion}

\section{Effects of elevated $\mathrm{O}_{3}$}

Many authors have found that photosynthetic processes are very sensitive to high $\mathrm{O}_{3}$, and a decrease in the rate of light-saturated net photosynthesis as a result of exposure to elevated $\mathrm{O}_{3}$ has been reported (Farage and Long, 1999). In our experiment, from the apparent decreases in $\mathrm{P}_{\mathrm{n}}$ of $Q$. mongolica leaves under EO fumigation appear in early of the growing season, It can be concluded that EO has a severe impact on $\mathrm{P}_{\mathrm{n}}$ of $Q$. mongolica leaves and $Q$. mongolica is an $\mathrm{O}_{3}$-sensitive tree species. Since Bortier et al. (2000) suggested that faster growing species tend to be more sensitive than slower growing species. Also compared with mature trees, young trees are more susceptible to $\mathrm{O}_{3}$ stress because of their high metabolic activity (Laurence et al., 1994). The sensitivity of $Q$. mongolica to EO in our experiment may be related to their young age. It has been correlated observed that photosynthesis decreased with a reduction in stomatal conductance under $\mathrm{O}_{3}$ exposure (Mansfeld, 1998). In other cases it was assumed that the decline in photosynthetic rate was the result of the interaction of $\mathrm{O}_{3}$ with photosynthetically active mesophyll cells (Farage and Long, 1995).

Stomatal conductance plays an important role in the photosynthetic efficiency of $\mathrm{O}_{3}$ stressed plants by controlling the amount of pollutant entering the plants through the stomata (Matyssek et al., 2004). It is well known that species with high stomatal conductance are more prone to injury because of enhanced pollutant uptake (Matyssek et al., 2004). Our results showed that $\mathrm{g}_{\mathrm{s}}$ of $Q$. mongolica leaves were significantly decreased by EO at the beginning of the experiment, while the similar decrease was appeared in $T_{r}$ of leaves. These results indicate that the partial closure of stomata can be induced by EO to avoid the further ozone uptake. Stomatal limitation is mainly attributed to stomata closure and, subsequently, to the decrement of $\mathrm{Ci}$ under normal conditions (Salazar-Parra et al., 2015), however, many authors suggested 
that stomata closure is not a direct response to $\mathrm{O}_{3}$ insult, but a reaction to an increased intercellular $\mathrm{CO}_{2}$ concentration resulted from the inhibition of carbon assimilation (Weber et al., 1993; Heath and Taylor, 1997). In our study, there was nearly no increase in $\mathrm{C}_{\mathrm{i}}$ of leaves under EO, compared to the control at 15 days when $\mathrm{g}_{\mathrm{s}}$ of leaves had decreased to minimum, so we propose that the stomata closure maybe associated with the direct effect of EO on guard cells of $Q$. mongolica leaves.

In low $\mathrm{O}_{3}$ environments, photosynthesis and stomatal conductance are typically tightly coupled because the stomatal aperture equivalently controls the exchange of $\mathrm{CO}_{2}$ and water at the leaf surface (Lombardozzi et al., 2012). However, from our study we can see that the typical coupling of stomatal conductance and photosynthesis does not always hold under EO and the decreases in $\mathrm{P}_{\mathrm{n}}$ can be independent (in some extent) of $\mathrm{g}_{\mathrm{s}}$, suggesting that decreases in carboxylation, rather than $\mathrm{g}_{\mathrm{s}}$, are responsible for decreases in $P_{n}$.

The reduction in photosynthesis may also occur due to structural damage of thylakoids, which affects the photosynthetic electron transport and is indicated by the reduction in $F_{v} / F_{m}$ ratio (Rai and Agrawal, 2012). $F_{v} / F_{m}$ ratio is an indicator of the photoinhibition to PS II complexes. Under $\mathrm{O}_{3}$ exposure, there are reports on wheat and rice showing increase in $\mathrm{F}_{0}$ and a parallel decrease in $\mathrm{F}_{\mathrm{m}}$, suggesting impairment of PS II activity (Feng et al., 2011; Ishii et al., 2004). In our experiment, in the end of season, under $\mathrm{EO}$ exposure (after 75 days), there were decreases of $\mathrm{F}_{0}, \mathrm{~F}_{\mathrm{m}}$ and $\mathrm{F}_{\mathrm{v}} / \mathrm{F}_{\mathrm{m}}$. Decreases of $\mathrm{F}_{0}$ and $\mathrm{F}_{\mathrm{v}} / \mathrm{F}_{\mathrm{m}}$ are the characteristics of thermal dissipation which depend on xanthophyll cycle and that dissipation reduces the photon energy to the photochemical reaction center $(\mathrm{Xu}, 2002)$. This can be seen as an important protection mechanism to avoid the destruction of PSII reaction centre. The decreases of $F_{0}, F_{m}$ and $F_{v} / F_{m}$ indicate that $\mathrm{O}_{3}$ can limit the capability of the plant to use photon energy and thus alter photosynthetic processes. Decrease in the $\mathrm{F}_{\mathrm{v}} / \mathrm{F}_{\mathrm{m}}$ is generally attributed to damage to the PSII reaction centre, apart from the down-regulation of the capacity of PSII electron transport (Chaumont et al., 1995).

Increased stomatal density seems to be a consistent effect related to ozone exposure and has been reported by Matyssek et al. (1991), but the same result was not found in this study, there were nearly no significant differences of stomatal parameters under EO compared to the control.

\section{Effects of elevated $\mathrm{CO}_{2}$}

Rising $\mathrm{CO}_{2}$ will impact plants through two processes, reducing $\mathrm{g}_{\mathrm{s}}$ and increasing $\mathrm{P}_{\mathrm{n}}$ (Ainsworth and Rogers, 2007). It has been reported that elevated $\mathrm{CO}_{2}$ stimulated lightsaturated photosynthesis in $\mathrm{C}_{3}$ plants (Ainsworth and Rogers, 2007; Lahive et al., 2018; Panigrahi et al., 2016). In our experiment, EC also increased $\mathrm{P}_{\mathrm{n}}$ of $Q$. mongolica leaves generally in two growing seasons until in the late of the second season (after 90 days).

Decreases in $\mathrm{g}_{\mathrm{s}}$ of some plants induced by high $\mathrm{CO}_{2}$ have been measured (Gao et al., 2012). However, the $\mathrm{CO}_{2}$-sensing mechanism in guard cells that is responsible for the short-term sensitivity of $\mathrm{g}_{\mathrm{s}}$ to elevated $\mathrm{CO}_{2}$ is still unknown (Ainsworth and Rogers, 2007). In our experiment, EC decreased $g_{s}$ slightly. Interestingly, unstressed plants tend to express a rather conservative range of $\mathrm{C}_{\mathrm{i}}$ during steady-state photosynthesis, $\mathrm{C}_{\mathrm{i}}$ is generally maintained at $0.7 \mathrm{C}_{\mathrm{a}}$ (concentration of ambient $\mathrm{CO}_{2}$ ) even when $\mathrm{C}_{\mathrm{a}}$ is varied (Drake and Gonzàlez-Meler, 1997). In our experiment, $\mathrm{C}_{\mathrm{i}}$ of leaves under EC was generally higher than under ambient $\mathrm{CO}_{2}$ treatments, that means perhaps change in $\mathrm{C}_{\mathrm{i}}$ is closely related to $\mathrm{C}_{\mathrm{a}}$, and it also may be the reason of why $\mathrm{g}_{\mathrm{s}}$ was decreased by EC. 
Shifts in stomatal function and morphological response to $\mathrm{CO}_{2}$ are likely to affect transpiration rates under rising atmospheric $\mathrm{CO}_{2}$. In our study, reduction of stomatal aperture and conductance $\left(\mathrm{g}_{\mathrm{s}}\right)$ explains the reduction in $\mathrm{T}_{\mathrm{r}}$ observed in plants grown in EC.

Stomata display a wide range in short-term behavioral and long-term morphological responses to atmospheric $\mathrm{CO}_{2}$ concentration (Haworth et al., 2013). In the short term, stomatal aperture generally decreases in response to high $\mathrm{CO}_{2}$, as described earlier. In the long term, decreases in $\mathrm{g}_{\mathrm{s}}$ can be caused by changes in stomatal density, as well as stomatal aperture (Ainsworth and Rogers, 2007), in the other hand, changes in leaf stomatal densities which in turn can control maximum values of stomatal conductance.

Ainsworth and Rogers' study (2007) showed that elevation of $\mathrm{CO}_{2}$ in FACE experiments reduced stomatal conductance by $22 \%$, yet this reduction was not associated with a similar change in stomatal density. However, some researchers believe that plants adapt to the elevated $\mathrm{CO}_{2}$ by reducing their stomatal density (that is, the number of stomata per unit of epidermal surface area) (Engineer et al., 2014). One expectation at increased $\mathrm{C}_{\mathrm{a}}$ is that fewer stomata are required because the rate of $\mathrm{CO}_{2}$ diffusion into the leaf will be a decreasing limitation to photosynthesis as $C_{a}$ rises (Drake and Gonzàlez-Meler, 1997). While in our experiment, there were no difference in stomatal density of mature $Q$. mongolica leaves detected among all treatments on 60th day (in the first season), but at the end of the second season (210th day), a significant decrease in stomatal density in response to EC was shown. Perhaps high $\mathrm{CO}_{2}$ was detected by mature leaves in the first year and signaled to developing leaves in the next year, whose stomatal developments altered accordingly (Lake et al., 2001). Researchers believed that those species with little or no control of stomatal aperture (termed passive) to $\mathrm{C}_{\mathrm{a}}$ were more likely to exhibit a reduction in stomatal density than species with active stomatal control when grown in atmospheres of elevated $\mathrm{CO}_{2}$ (Haworth et al., 2013), that is perhaps why there was only a slight decrease in $\mathrm{g}_{\mathrm{s}}$ of leaves detected in our experiment.

Modification to stomata abundance and size as a stress response is also stated an important pollutant absorption-controlling mechanism, and these parameters mutually affected each other. An inverse relationship between stomatal pore length or size and stomatal density has been observed in the gas exchange responses of plants in response to increased $\mathrm{CO}_{2}$. However, a similar pattern was not observed in the species analyzed in Haworth's study (2013). While in our study, we can only see a slight increase in stomatal width of leaves in EC on 60th day $(\mathrm{P}<0.05)$.

\section{Effects of elevated $\mathrm{CO}_{2}$ and $\mathrm{O}_{3}$}

It is concluded that season-long exposure to elevated $\mathrm{CO}_{2}$ had a greater effect on photosynthetic parameters than elevated $\mathrm{O}_{3}$ (Alison et al., 2001), while this result is opposite to ours. When high $\mathrm{O}_{3}$ and high $\mathrm{CO}_{2}$ were given in our experiment, $\mathrm{P}_{\mathrm{n}}$ of leaves was still lower than control in the whole growing season except at the end of the season. It is also found that the combination of elevated $\mathrm{O}_{3}$ and $\mathrm{CO}_{2}$ can led to a significant decrease in the light-saturated rate of photosynthesis, but compared to elevated $\mathrm{O}_{3}$ alone, the level of decrease was lower (Kellomäki and Wang, 1997). The study of the combined effects of elevated $\mathrm{CO}_{2}$ and $\mathrm{O}_{3}$ on photosynthesis show that elevated $\mathrm{CO}_{2}$ compensated most of the adverse effects of $\mathrm{O}_{3}$ (Reid and Fiscus, 1998). In our study, $\mathrm{P}_{\mathrm{n}}$ of $Q$. mongolica leaves under $\mathrm{EO}+\mathrm{EC}$ were nearly all significantly higher than EO in the whole seasons $(\mathrm{p}<0.05)$. This suggests that $\mathrm{O}_{3}$-induced adverse effects 
to photosynthesis can be ameliorated, at least partly, by high $\mathrm{CO}_{2}$, but the complete mechanism behind this interaction is, however, still unclear.

There was no significant difference of $\mathrm{g}_{\mathrm{s}}$ between the combination and EO treatments except after 60 days in the second season, which was mainly caused by EO but not EC.

It is found there was a significant interaction between elevated $\mathrm{CO}_{2}$ and increased $\mathrm{O}_{3}$, elevated $\mathrm{O}_{3}+\mathrm{CO}_{2}$ led to a $14 \%$ decrease in $\mathrm{F}_{\mathrm{v}} / \mathrm{F}_{\mathrm{m}}$ compared to the control (Kellomäki and Wang, 1997). While in this experiment, there was no significant difference in $F_{v} / F_{m}$ detected under the combined treatment, compared to the control. High $\mathrm{CO}_{2}$ can largely relieve the adverse effects of high $\mathrm{O}_{3}$ to PSII reaction center.

Changes in stomatal parameters of $Q$. mongolica leaves under EO+EC were just like the changes of them under only EC exposure. Perhaps the effect of stomatal morphology was mainly caused by EC but not EO.

\section{Conclusion}

Q. mongolica is an $\mathrm{O}_{3}$-sensitive tree species and EO had a severe impact on $\mathrm{P}_{\mathrm{n}}$ of $Q$. mongolica leaves because of their young age. $\mathrm{g}_{\mathrm{s}}$ and $\mathrm{T}_{\mathrm{r}}$ of leaves was significantly decreased by EO at the beginning of the experiment, which indicates that the partial closure of stomata can be induced by EO to avoid the further ozone uptake. The stomata closure maybe associated with the direct effect of EO on guard cells. Under EO, there were decreases in $F_{0}, F_{m}$ and $F_{v} / F_{m}$ at the end of the season (after 75 days). This indicates EO can limit the capability of the plant to use photon energy and thus alter photosynthetic processes; EC generally increased $\mathrm{P}_{\mathrm{n}}$ of $Q$. mongolica leaves, but decreased $g_{s}$ slightly. The decrease of $g_{s}$ is thought to maintain the ratio of $C_{i}$ and $C_{a}$, and regulate the WUE of trees. A significant decrease in stomatal density in response to EC was shown only at the end of the second season (210th day) but not in the first season. Maybe, EC was detected by mature leaves in the first growing season and signaled to developing leaves in the next growing season, whose stomatal developments altered accordingly; Under EO+EC, $\mathrm{P}_{\mathrm{n}}$ of leaves were still lower than that control, but nearly all significantly higher than EO in the whole seasons $(\mathrm{p}<0.05)$. This suggests that $\mathrm{O}_{3}$-induced adverse effects to photosynthesis can be ameliorated, at least partly, by $\mathrm{CO}_{2}$. The decrease in $\mathrm{g}_{\mathrm{s}}$ was mainly caused by EO but not EC. There was no significant difference in $\mathrm{F}_{\mathrm{v}} / \mathrm{Fm}$ detected under $\mathrm{EO}+\mathrm{EC}$, compared to control. EC can largely relieve the adverse effects of EO to PSII reaction center. Changes in stomatal parameters of leaves under EO+EC were just like the changes of them under only EC. Perhaps the effect of stomatal morphology was mainly caused by EC, but not EO.

Acknowledgements. The authors wish to thank Prof. Tao for his help in revision of manuscript. This work was founded by the National Natural Science Foundation of China (31600314) and Major Incubating Project of Shenyang Normal University.

\section{REFERENCES}

[1] Akimoto, H., Mori, Y., Sasaki, K., Nakanishi, H., Ohizumi, T., Itano, Y. (2015): Analysis of monitoring data of ground-level ozone in Japan for long-term trend during 1990-2010: causes of temporal and spatial variation. - Atmos Environ 102: 302-310. 
[2] Alison, D., Jim, C., Colin, R. B., Jeremy, J. C., Geoff, L. (2001): Does elevated $\mathrm{CO}_{2}$ ameliorate the impact of $\mathrm{O}_{3}$ on chlorophyll content and photosynthesis in potato (Solanum tuberosum)? - Physiol Plant 111: 501-511.

[3] Bortier, K., Temmerman, L., Ceulemans, R. (2000): Effects of ozone in open-top chambers on poplar (Populus nigra) and beech (Fagus sylvatica): a comparison. Environ Pollut 109: 509-516.

[4] Chaumont, M., Morot-Gaudry, J. F., Foyer, C. H. (1995): Effects of photoinhibitory treament on $\mathrm{CO}_{2}$ assimilation, the quantum yield of $\mathrm{CO}_{2}$ assimilation, $\mathrm{D}_{1}$ protein, ascorbate, glutathione and xanthophy II contents and the electron transport rate in vine leaves. - Plant Cell Environ 18: 1358.

[5] Drake, B. G., Gonzàlez-Meler, M. A. (1997): MORE EFFICIENT PLANTS: A Consequence of Rising Atmospheric $\mathrm{CO}_{2}$ ? - Annu Rev Plant Physiol Plant Mol Biol 48: 609-639.

[6] Engineer, C. B., Ghassemian, M., Anderson, J. C., Peck, S. C., Hu, H. H., Schroeder, J. I. (2014): Carbonic anhydrases, EPF2 and a novel protease mediate $\mathrm{CO}_{2}$ control of stomatal development. - Nature 513: 246-250.

[7] Farage, P. K., Long, S. P. (1995): An in vivo analysis of photosynthesis during short-term $\mathrm{O}_{3}$ exposure in three contrasting species. - Photosyn Res 43: 11-18.

[8] Farage, P. K., Long, S. P. (1999): The effects of $\mathrm{O}_{3}$ fumigation during leaf development on photosynthesis of wheat and pea: an in vivo analysis. - Photosynth Res 59: 1-7.

[9] Feng, Z., Pang, J., Kobayashi, K., Zhu, J., Orts, D. R. (2011): Differential responses in two varieties of winter wheat to elevated ozone concentration under fully open-air field conditions. - Global Change Biol 17: 580-591.

[10] Feng, Z. Z., Hu, E. Z., Wang, X. K., Jiang, L. J., Liu, X. J. (2015): Ground-level O pollution and its impacts on food crops in China: a review. - Environ Pollut 199: 42-48.

[11] Frey, B., Scheidegger, C., Günthardt-goerg, M. S., Matyssek, R. (1996): The effects of ozone and nutrient supply on stomatal response in birch (Betula pendula) leaves as determined by digital image-analysis and X-ray microanalysis. - New Phytol 132: 135143.

[12] Gao, C. J., Xia, X. J., Shi, K., Zhou, Y. H., Yu, J. Q. (2012): Response of stomata to global climate changes and the underlying regulation mechanism of responses. - Plant Physiology Journal 48: 19-28.

[13] Gao, J., Han, X., Seneweera, S., Li, P., Zong, Y. Z., Dong, Q., Lin, E. D., Hao, X. Y. (2015): Leaf photosynthesis and yield components of mung bean under fully open-air elevated $\left[\mathrm{CO}_{2}\right]$. - J Integr Agr 14: 977-983.

[14] Guo, H. G., Wang, S. F., Ge, F. (2017): Effect of elevated $\mathrm{CO}_{2}$ and $\mathrm{O}_{3}$ on phytohormonemediated plant resistance to vector insects and insect-borne plant viruses. - Sci China Life Sci 60: 816-825.

[15] Haworth, M., Elliott-Kingston, C., McElwain, T. C. (2013): Co-ordination of physiological and morphological responses of stomata to elevated $\left[\mathrm{CO}_{2}\right]$ in vascular plants. - Oecologia 171: 71-82.

[16] He, X. Y., Ruan, Y. N., Chen, W., Lu, T. (2006): Responses of the anti-oxidative system in leaves of Gingo biloba to elevated ozone concentration in an urban area. - Bot Stud 47: 409-416.

[17] Heath, R. L., Taylor, G. E. (1997): Physiological Processes and Plant Responses to Ozone Exposure. - In: Sandermann, H., Wellburn, A. R., Heath, R. L. (eds.) Forest Decline and Ozone. Ecological Studies 127. Springer-Verlag, Berlin, pp. 317-368.

[18] IPCC (Intergovernmental Panel on Climate Change) (2007): Climate Change: The Physical Science Basis. - In: Solomon, S. Q. D., Manning, M., Chen, Z., Marquis, M., Averyt, K. B., Tignor, M., Miller, H. L. (ed.) Contribution of Working Group I to the Fourth Annual Assessment Report of the Intergovernmental Panel on Climate Change. Cambridge Univ. Press, Cambridge. 
[19] IPCC (2013): Climate change: The Scientific Basis. - http://www.ipcc.ch/ pdf/assessment -report/ ar5/wg1/WGIAR5_SPM_brochure_en.pdf.

[20] Ishii, S., Marshall, F. M., Bell, J. N. B. (2004): Physiological and morphological responses of locally grown Malaysian rice cultivars (Oryza sativa L.) to different ozone concentrations. - Water Air Soil Pollut 155: 205-221.

[21] Kellomäki, S., Wang, K. Y. (1997): Effects of elevated $\mathrm{O}_{3}$ and $\mathrm{CO}_{2}$ on chlorophyII fluorescence and gas exchange in scots pine during the third growing season. - Environ Pollut 97: 17-27.

[22] Lahive, F., Hadley, P., Daymond, A. J. (2018): The impact of elevated $\mathrm{CO}_{2}$ and water deficit stress on growth and photosynthesis of juvenile cacao (Theobroma cacao L.). Photosynthetica 56: 911-920.

[23] Lake, J. A., Quick, W. P., Beerling, D. J., Woodward, F. I. (2001): Plant development signals from mature to new leaves. - Nature 411: 154-154.

[24] Laurence, J. A., Amudson, R. G., Friend, A. L., Pell, E. J., Temple, P. J. (1994): Allocation of carbon in plants under stress: an analysis of the ROPIS experiments. $-\mathbf{J}$ Environ Qual 23: 412-417.

[25] Lombardozzi, D., Sparks, J. P., Bonan, G., Levis, S. (2012): Ozone exposure causes a decoupling of conductance and photosynthesis: implications for the Ball-Berry stomatal conductance model. - Oecologia 169: 651-659.

[26] Mansfield, T. A. (1998): Stomata and plant water relations: does air pollution create problems? - Environ Pollut 101: 1-11.

[27] Matyssek, R., Günthardt-Goerg, M. S., Keller, T., Scheidegger, C. (1991): Impairment of gas exchange and structure in birch leaves (Betula pendula) caused by low ozone concentrations. - Trees 5: 5-15.

[28] Matyssek, R., Wieser, G., Nunn, A. J., Kozovits, A. R., Reiter, I. M., Heerdt, C., Winkler, J. B., Baumgarten, M., Häberle, K. H. (2004): Comparison between AOT40 and ozone uptake in forest trees of different species, age and site conditions. - Atmos Environ 38: 2271-2281.

[29] Panigrahi, S., Pradhan, M. K., Panda, D. K., Panda, S. K., Joship, N. (2016): Diminution of photosynthesis in rice (Oryza sativa L.) seedlings under elevated $\mathrm{CO}_{2}$ concentration and increased temperature. - Photosynthetica 54: 359-366.

[30] Rai, R., Agrawal, M. (2012): Impact of tropospheric ozone on crop plants. - Proc Natl Acad Sci India Sect B Biol Sci 82: 241-257.

[31] Reid, C. D., Fiscus, E. L. (1998): Effects of elevated $\left[\mathrm{CO}_{2}\right]$ and/or ozone on limitations to $\mathrm{CO}_{2}$ assimilation in soybean (Glycine max). - J Exp Bot 49: 885-895.

[32] Salazar-Parra, C., Aranjuelo, I., Pascual, I. Erice, G., Sanz-Sáez, Á., Aguirreolea, J., Sánchez-Díaz, M., Irigoyen, J. J., Araus, J. L., Morales, F. (2015): Carbon balance, partitioning and photosynthetic acclimation in fruit-bearing grapevine (Vitis vinifera L. cv. Tempranillo) grown under simulated climate change (elevated $\mathrm{CO}_{2}$, elevated temperature and moderate drought) scenarios in temperature gradient greenhouses. - J Plant Physiol 174: 97-109.

[33] Serengil, Y., Augustaitis, A., Bytnerowicz, A., Grulke, N., Kozovitz, A. R., Matyssek, R., Müller-Starck, G., Schaub, M., Wieser, G. (2011): Adaptation of forest ecosystems to air pollution and climate change: a global assessment on research priorities. - iFores 4: 4448.

[34] Verstraeten, W. W., Neu, J. L., Williams, J. E., Bowman, K. W., Worden, J. R., Boersma, K. F. (2015): Rapid increases in tropospheric ozone production and export from China. Nature Geosci 8: 690-695.

[35] Wang, L. L., He, X. Y., Chen, W. (2009): Effects of elevated ozone on photosynthetic $\mathrm{CO}_{2}$ exchange and chlorophyll a fluorescence in leaves of quercus mongolica grown in urban area. - Bull Environ Contam and Toxico 82: 478-481. 
[36] Weber, J. A., Clark, C. S., Hogsett, W. E. (1993): Analysis of the relationships among $\mathrm{O}_{3}$ uptake, conductance, and photosynthesis in needles of Pinus ponderosa. - Tree Physiol 13: 157-172.

[37] Woodward, F. I. (1987): Stomatal numbers are sensitive to increases in $\mathrm{CO}_{2}$ from preindustrial levels. - Nature 327: 617-618.

[38] Xu, D. Q. (2002): Efficiency of Photosynthesis. - Shanghai Science and Technology Press, Shanghai. 